\title{
DIE IDENTIFISERING VAN DIE ELEMENTE WAARUIT WERKSPANNING BESTAAN
}

\author{
F. VAN GRAAN \\ DEPARTEMENT BEDRYFSIELKUNDE \\ VAALRIVIERTAK, P.U. VIR C.H.O.
}

\begin{abstract}
SUMMARY
The investigation was directed at developing a questionnaire for measuring work stress. The questionnaire was administered to 112 white employees of a regional branch of a national organisation, followed by interviews based on random sampling. Seven stress producing experiences were identified, namely over load, frustration, insecurity, conflict, lack of interest, dependence and anxiety. The experience yielding the highest response average was dependence, while worry, frustration and insecurity attained the second, third and fourth highest response average scores respectively.
\end{abstract}

Die begrip "spanning" word baie in die alledaagse lewe gebruik. Spanning is egter 'n samevattende begrip vir 'n komplekse ervaringsveld. Min aandag is op wetenskaplike basis gegee aan die oorsaak en gevolg van psigologiese spanning in die werksituasie. Daarom is daar met hierdie studie gepoog om deur middel van bestaande wetenskaplike kennis en begrippe, die voorkoms en aard van spanning in die werksituasie te ondersoek.

Die begrip spanning het tot die psigologie gekom via die fisika en die ingenieurswese en later die biologiese wetenskappe. Alhoewel die begrip "psigologiese spanning" verskil van die natuurwetenskaplike begrip "spanning" het die term spanning al gou veel aandag geniet en volgens Appley (1967) veral om die volgende rede:

Dit is ' $\mathrm{n}$ samevattende begrip wat die gevolg kan wees van " $\mathrm{n}$ groot aantal toestande wat kan heers soos angs, konflik, emosionele ongesteldhede, uiterste omgewingstoestande, frustrasie en bedreiging van sekuriteit. Buck (1972) beweer tewens dat die werker nie onderskeid maak tussen konflik, vrees en angs nie. Die werker is so behep met die oplossing van die onmiddellike negatiewe ervaring dat hy die negatiewe ervaring slegs ervaar en nie klassifiseer nie.

\footnotetext{
*Erkenning word met dank verleen aan die Algemene Buro vir Ekonomiese Navorsing (PU vir CHO) vir finansiële hulp.
} 
Die pionier op die gebied van die omskrywing van die begrip spanning is Hans Selyé wat in 1936 'n artikel publiseer met die titel "A syndrome produced by diverse nocuous agents". Hieruit ontstaan die bekende GAS (General Adaption Syndrome) in Afrikaans bekend as die A A S (Algemene Aanpassingsindroom).

\section{OMSKRYWING VAN DIE BEGRIP SPANNING}

\section{Die totale veld van die begrip}

- $\quad$ Spanning word die beste waargeneem as " $n$ toestand van die totale organisme eerder as wat dit beskou word as ' $n$ gebeurtenis in die omgewing. Twee aspekte is hier van belang. Spanning is eerder ' $\mathrm{n}$ toestand soos ervaar deur die organisme as wat die organisme dit as ' $n$ element van die omgewing beskou. Die toestand word egter deur die totale organisme ervaar. Daarmee word die intergebondenheid van psigologiese en fisiologiese spanning aangetoon. So, byvoorbeeld, gaan pyn gepaard met 'n emosionele gevoel van terneergedruktheid en depressie.

- $\quad$ 'n Groot verskeidenheid omgewingstoestande is in staat om 'n spanningstoestand in die organisme te laat voorkom. Verskillende individue respondeer op dieselfde toestande op verskillende wyses. Sommige gaan vinnig 'n toestand van spanning binne, ander toon 'n toename in helderheid en skynbare verbetering in prestasie en ander blyk "immuun" te wees teen spanningsproduserende faktore van die omgewing.

- Konstante intra-individuele maar verskillende inter-individuele psigofisiologiese response word verkry.

- Die gedrag wat voortvloei uit situasies wat daarop gerig is om spanning te ontlok kan dieselfde wees of verskil afhangende van die konteks van die situasies.

- Die intensiteit van die ervaarde spanning en die daarmee gepaardgaande gedrag kan miskien nie so maklik van die kennis van die stimulus alleen afgelei word nie, maar vereis ' $n$ analise van die onderliggende motiveringspatrone en die verband waarin die spanningstimulus toegepas word.

\section{Die definiëring van die begrip "spanning"}

Soos verskeie ander skrywers onderskei Lazarus (1969) tussen 'n stimulusdefinisie en 'n responsdefinisie van spanning. Ten opsigte van die stimulusdefinisie van spanning is dit ' $n$ 
eksterne toestand wat buitengewone eise aan die individu stel of wat hom op een of ander manier bedreig. Die definisie sluit 'n geweldige hoeveelheid veranderlikes in soos oorlogvoering, natuurrampe, vrees vir die dood en nog veel ander. Nogtans word dit al gou duidelik dat die stimulusdefinisie van spanning heeltemal onvoldoende blyk te wees omdat daar geen ooreenstemmende wyse is waarop alle individue op spanning sal reageer nie. Indien spanning so gedefinieer word, sal daar altyd 'n kwalifikasie bygevoeg moet word, wat inhou dat die situasie as spanningskwalifikasie bygevoeg moet word, wat inhou dat die situasie as spanningsbelaaid beskou kan word slegs indien die individu dit as sodanig interpreteer.

Daarom word voorkeur gegee aan die responsdefinisie van spanning wat betrekking het op die reaksies van die persoon wat die spanningstimulus ervaar. Dit bring mee dat spanning gemeet kan word. Wanneer die individu onder spanning verkeer openbaar die individu sekere simptome wat ooreenkom met die simptome van ander persone.

Uitgaande van dié standpunt kan spanning soos volg omskryf word: Spanning is meer individu-gebonde as situasiegebonde. Dit is 'n ervaring wat deur die individu ondervind word as gevolg van intra-persoonlike toestande en omgewingstoestande waarop die individu op 'n kragdadige wyse reageer om so gou moontlik en met die minste koste weer na 'n toestand van homeostase terug te keer.

Met dié omskrywing word egter nie oppervlakkig gesuggereer dat spanning bloot ' $n$ weerstand teen enige verandering is nie. Spanning is ook nie slegs enige ervaring nie, maar wel ' $n$ negatiewe ervaring. Dit is nie gelykmatig nie maar veeleisend. Dit is nie net bloot ' $n$ abstrakte "toestand" nie maar 'n ervaarde toestand waarop die individu op 'n bepaalde wyse reageer.

\section{INDIVIDUELE FAKTORE WAT DIE ERVARING VAN SPANNING BEPAAL}

Volgens Lazarus (1969) beskou die individu die spanningstimulus as 'n bedreiging vir homself. Bedreiging vir ' $n$ individu hou in die antisipasie van een of ander negatiewe effek. Hoe ernstiger die geantisipeerde negatiewe effek, hoe groter die bedreiging en hoe meer intens die emosionele reaksie van die individu om die bedreiging die hoof te bied. Die begrip bedreiging hou ook in dat die individue die situasie moet evalueer. Die evaluasies is gebaseer op vorige ervarings en die leerproses. Situasies wat nie in die verlede as negatief ervaar is nie, sal nie as bedreigend geïnterpreteer word nie, ten spyte van die feit dat die situasie as gevolg van die verandering in die fisiese omgewing wel 'n bedreiging vir die individu kan inhou. 
Verskeie aspekte van die situasie bepaal die beoordeling daarvan waarvan die volgende vier deur Lazarus (1969) bespreek word:

\section{Die hulpeloosheid van die individu}

Bedreiging hang af van die mate waarin die persoon homself bekwaam beskou om die gevaar te hanteer. As " $n$ persoon homself bekwaam beskou om die gevaar af te weer is die bedreiging minimaal. Bedreiging neem egter toe as die persoon homself te hulpeloos of te swak voel om die gevaar af te weer mits dit in ag geneem word dat die ernstigheidsgraad van die bedreiging direk verband hou met die ernstigheidsgraad van die gevaar.

\section{Die afstand van die bedreiging}

Indien die bedreiging verafgeleë is ten opsigte van afstand en tyd sal die graad van bedreiging wat deur die individu ervaar word kleiner wees.

\section{Motiveringspatroon}

Die graad van bedreiging deur enige stimulussituasie word bepaal deur die behoeftes en die motiewe van die individu. Indien die toekomstige bedreiging irrelevant is ten opsigte van die persoon se doelstellings, sal die bedreiging as minimaal ervaar word. Indien die frustrasie van ' $n$ belangrike doel egter geantisipeer word, sal die persoon wel bedreiging ervaar en die mate van bedreiging wat ervaar word, sal toeneem namate die belangrikheid van die doel wat bedreig word vir die individu toeneem.

Algemene gelowe ten opsigte van die omgewing en die individu se vermoë om die omgewing te hanteer

Gelowe ten opsigte van die wêreld wat 'n gevaarlike plek is en die aanname dat die individu magteloos staan teenoor die omgewing lei dikwels tot 'n gevoel van verslaentheid en tot chroniese angsgevoelens. Deur middel van kondisionering kan die individu wat herhaalde ervarings het van mislukking in die afweer van die bedreiging die bedreiging as "normaal" aanvaar en uit die aard van die saak nie veel daaraan doen om die bedreiging af te weer nie.

\section{Die toleransievlak van spanning}

Volgens Appley en Trumbull (1967) is dit te betwyfel of daar so iets soos ' $n$ algemene spanningsdrempel bestaan. Daar is, meer waarskynlik, beter of swakker isolasie van die effek van sekere spanningstimuli as andere. Die algemene idee van 'n spanningsdrempel is dat die 
stimulus eers 'n sekere intensiteit moet bereik voordat dit spanning sal induseer. Dit lyk meer waarskynlik dat daar verskillende drempels is, afhangende van die tipe bedreiging wat teëgekom word en dat individue op verskillende wyses vatbaar sal wees vir die verskillende soorte spanningsagente. Om vas te stel watter tipe spanningsagent effektief sal wees vir watter persoon, sal die motiveringstruktuur van die persoon in aanmerking geneem moet word.

\section{GEVOLGE VAN SPANNING}

Een van die vernaamste gevolge van spanning is psigomatiese simptome soos hartdisfunksies en gastro-intestinale steuringe. So het Caplan en Jones (1975) in 'n eksperiment met die gebruikers van rekenaars gevind dat daar ' $n$ positiewe verband is tussen subjektiewe kwalitatiewe taakbelasting en die verandering in die angsvlak van die individu. Verandering in die angsvlak het egter positief gekorreleer met ' $n$ verhoging in hartslag.

Verskeie skrywers het al gewys op die groter voorkoms van maagsere onder bestuurders as onder gewone werkers. Al die skrywers wys ook daarop dat die verhoging in die aantal maagsere toe te skryf is aan die verhoging in die vlak van spanning namate daar hoër in die bestuurshiërargie beweeg word. So het Doll en Jones (1951) toesighouers en uitvoerende beamptes vergelyk met hulle ondergeskiktes en gevind dat die toesighouers en uitvoerende beamptes 'n groter voorkoms van maagsere getoon het. Vertin (1954) het in 'n groot onderneming wat elektriese toebehore in Nederland vervaardig, gevind dat toesighouers ' $\mathrm{n}$ groter voorkoms van maagsere toon as diegene waaroor daar toesiggehou word, Pflanz et al. (1956), Gosling (1958) en Cobb (1963) (soos aangehaal deur McLean, 1974), het dieselfde resultate in die VSA verkry.

Reeds in 1949 het Mahl gevind dat spanning en die hoeveelheid soutsuur in die maag verband hou met mekaar. Hy het gevind dat daar "n substansiële toename is in die hoeveelheid soutsuur onder toestande van chroniese psigologiese spanning en 'n besliste afname in die hoeveelheid soutsuur by 'n toestand van verminderde spanning.

Ander skrywers het ook die verband tussen spanning en die misbruik van verdowingsmiddels ondersoek. So wys Rogers en Colbert (1975) daarop dat die meerderheid bestuurders van sienswyse is dat die misbruik van verdowingsmiddels " $n$ direkte gevolg is van inherente swakheid - die onvermoë van die individu om 'n groot aantal persoonlike probleme te hanteer, maar .... "drug use often occurs not so much for the pleasure, but to reduce displeasure ... it 
has been suggested that some drug use is a by product of today's highly impersonal working environment which promote both boredom and stress ... " (p 266)

Cochrane en Robertson (1975) het die aard en die duur van die verhouding tussen spanning en selfmoordpogings bestudeer. Resultate van die studie toon aan dat $44 \%$ van die paraselfmoordenaars werkloos was teenoor $11 \%$ van die kontrolegroep, $17 \%$ het probleme ervaar met hulle toesighouers, teenoor $12 \%$ van die kontrolegroep, $22 \%$ het ' $n$ verandering in werksure en toestande van werk ervaar teenoor die $13 \%$ van die kontrolegroep. $27 \%$ se inkome het gedaal teenoor die $5 \%$ van die kontrolegroep.

Werkers wat onder intense psigologiese spanning verkeer makk dikwels foute in hul werk en misluk soms geheel en al. Altorfer (1975) het in "n ondersoek wat by "Japan Air Lines" gedoen is gevind dat die werkers selde foute maak omdat hulle nie weet hoe om die werk te doen nie. Die ondersoek het getoon dat $90 \%$ van die oorsake van die foute toegeskryf kan word aan emosies, verveeldheid, pre-okkupasie, spanning, vrees en traak-my-nieagtigheid.

Sales (1970) het tot dieselfde gevolgtrekking gekom nadat hy gevind het dat persone wat aan oorlading blootgestel word weliswaar 'n hoër produksie toon as persone wat nie oorlading ervaar nie, maar dat die vlak van spanning beduidend hoër is en dat dit lei tot oorhaastigheid en soms tot totale ineenstorting.

Ook Levinson (1968) wys daarop dat bestuurders wat nie in staat is om te onderskei tussen ' $n$ fisiese besering en psigologiese spanning nie, dikwels die intensiteit van die negatiewe gedrag verhoog wanneer, byvoorbeeld, groter verantwoordelikheid toegeken word aan ' $n$ werker wat alreeds veg om homself te beheer en te beskerm. Oormatige druk van toesighouers en bestuurders op " $n$ individu veroorsaak dan dat die bestuurder/toesighouer teen die individu moet optree. Veral waar die individu reeds in die verlede 'n merkbare bydrae gemaak het tot die organisasie, kan dit 'n intense skuldgevoel by die bestuurder/toesighouer meebring wat lei tot 'n hulpelose gevoel as gevolg van die gebrek aan insig in die probleem.

Werkers wat onder spanning verkeer, is ook meer geneig om 'n drukgroep te vorm teen bestuur (Argyris, 1957) en sodanige werkers wat in groepe (vakbonde) georganiseer is, is meer geneig om te staak as ongeorganiseerde groepe (Snyder, 1975).

Spanning bring ook 'n vermindering in werkstevredenheid mee (French en Caplan, 1972), asook ' $n$ verminderde mate van benutting van intellektuele vermoëns. Die organisasie lei ook daaronder deurdat minder gebruik gemaak word van potensialiteite. Individue in die 
organisasie voorsien weinig geleentheid vir bevordering omdat onsekerheid bestaan ten opsigte van bevorderingsmoontlikhede.

Dit is bo alle twyfel duidelik dat spanning ' $n$ pertinente invloed het op die individuele werker. Stremminge in die werksituasie kos die nywerheid in sy geheel baie in terme van geld, veral op die korttermyn maar nog veel meer op die langtermyn gesien in terme van arbeidsomset, opleidingskoste, verlies aan produksie en lae kwaliteit van produksie.

Spanning bring ook ' $\mathrm{n}$ daling in die geestesgesondheid van die individu mee. Geestesgesondheid word deur Kornhauser (1965) gedefinieer as: "those behaviours, attitudes, perceptions and feelings that determine a workers overall level of personal effectiveness, success, happiness, and excellence of functioning as a person ... " (p 11). Dit bring noodwendig ' $n$ daling in effektiwiteit mee wat kan lei tot ' $n$ daling in produksie, hetsy kwantitatief of kwalitatief.

Onbuigbaarheid in gedragspatrone wat verskil van die veranderlikheid van probleemoplossingsgedrag is nog ' $\mathrm{n}$ gevolg van spanning. Spanning kan ook hoë arbeidsomset meebring aangesien die individu binne ' $n$ bepaalde omgewing van die spanningstimuli probeer ontsnap deur die omgewing te verlaat. Die tweede, nuwe omgewing, sal die individu geneig wees om meer sensitief te wees vir nuwe bedreigings. Aangesien die individu subjektief betrokke is kan ' $n$ abnormale vergroting van die bedreiging plaasvind. By herhaalde mislukkings in die afweer van die bedreiging ervaar die individu ' $n$ afkraking van die selfbeeld wat hom juis vatbaar maak vir spanningstimuli. Die sirkel is voltooi.

Gesien in die lig van die voorafgaande is dit duidelik dat kommer oor spanning geregverdig is. Aan die ander kant bestaan daar 'n sterk vermoede dat bestuur nie genoegsaam hieroor bekommerd is nie. Die gebruik van spanning (druk) as aansporingsmiddel is oorbekend en 'n erkende bestuurstyl.

Hierdie studie probeer die volgende vrae beantwoord:

- $\quad$ Kan 'n metode ontwikkel word om psigologiese spanning vas te stel?

- Is daar ' $\mathrm{n}$ verband tussen die frekwensie en die intensiteit van spanning?

- $\quad$ Spanning word allerweë beskou as ' $n$ versamelnaam vir 'n klomp ervarings. Kan die ervarings geïsoleer en gekategoriseer word?

- $\quad$ Is daar ' $n$ enkele ervaring wat meer voorkom as ander? 


\section{Die organisasie}

Die organisasie wat betrek is by die ondersoek is die Wes-Transvaalse tak van ' $n$ landswye organisasie wat te doen het met dienslewering, produksie en instandhouding.

\section{Die proefgroep}

Die proefgroep het bestaan uit al 300 Blanke werknemers van die organisasie. Driehonderd vraelyste is aan die Personeeldepartement oorhandig vir verspreiding aan werknemers. Van die 300 vraelyste is 164 terugontvang. Van die vraelyste wat terugontvang is was 35 nie ingevul nie. Van die 129 wat wel ingevul was moes 17 vraelyste verwerp word aangesien dit óf verkeerd óf onvolledig ingevul was.

Saam met elke vraelys het die respondent ' $n$ gefrankeerde koevert ontvang met die ondersoeke se naam en adres daarop gedruk. Die respondent het dus die vraelys tuis voltooi en dit direk aan die ondersoeker teruggepos. Die totale aantal vraelyste wat gebruik is, is 112 .

\section{Die vraelys* \\ Responsalternatiewe}

$\mathrm{Al}$ die vrae is gestel op ' $\mathrm{n}$ vyfpunt responsalternatiewe skaal. Al die vrae is so gestel dat dit in dieselfde rigting meet. 'n Hoë telling dui dus altyd op 'n hoë mate van spanning.

\section{Elemente waaruit die vraelys bestaan}

Die vraelys is opgedeel in twee groepe faktore wat die frekwensie en die intensiteit van spanning kenmerk, naamlik primêre en sekondêre faktore. Onder primêre faktore word verstaan daardie faktore wat ooglopend saamhang met spanning maar waarvan die presiese verband nog nie bepaal is nie. Onder sekondêre faktore word daardie faktore verstaan wat heelwaarskynlik saamhang met spanning maar wat nog ondersoek moet word. Meer spesifiek behels die primêre en sekondêre faktore die volgende:

\footnotetext{
* ' $\mathrm{n}$ Kopie van die vraelys is van die outeur verkrygbaar. 
Primêre faktore

Frustrasie

Angs

Onsekerheid

Oorlading

Spanning

Kommer

Konflik
Sekondêre faktore

Verveling

Verlies van selfvertroue

Afhanklikheid

Aggressie

Passiwiteit

Groepsvorming teen bestuur

Verlies aan vertroue in bestuur en

medewerkers

Verwydering van interne doelwitte van

die organisasiedoelwitte

\section{Die frekwensie van spanning}

Die gedeelte van die vraelys bestaan uit 27 vrae wat gestel is aan die respondent op " $\mathrm{n}$ "hoe dikwels" basis. Twee en twintig van die 27 vrae bestaan uit twee vrae wat elke keer gekombineer is. Die eerste gedeelte van die vraag toets die frekwensie van spanning deur dit direk aan die respondent te vra terwyl die tweede gedeelte van die vraag spanning toets ten opsigte van dieselfde element deur gebruik te maak van die omskrywing van die element soos dit in die literatuur gevind word. Die rede hiervoor is dat in " $n$ verkenningstudie gevind is dat min werkers bereid is, of in staat is om die presiese aard van hulle gevoelens te analiseer. Die ander vyf vrae word slegs enkelvoudig gestel.

\section{Intensiteit van spanning}

Vir die elemente frustrasie, angs, onsekerheid, oorlading, spanning, kommer, konflik, verveling, verlies aan selfvertroue, afhanklikheid, aggressie en passiwiteit is ook vrae gestel om die intensiteit van die ervaring te toets. Dit is gedoen omdat slegs vae aanduidings in die literatuur verkry kon word van 'n verband tussen die frekwensie en die intensiteit van spanning. Die moontlike gevaar wat die ondersoeker hierdeur probeer ondervang het, is dat ' $n$ individu ' $n$ enkele intense ervaring van enige van die elemente kon beleef het en dat die antisipasie van ' $n$ herhaling van die gebeurtenis die beantwoording van die vraelys kon benadeel het. 
Die gebruik van die vraelys om spanning vas te stel

Dit is gewens dat die geldigheid van die vraelys getoets sou word. Erkende psigometriese tegnieke soos die Selfondersoek vraelys (IPAT) en die S.O.R.T. meet nie spanning nie maar eerder angs of angsvalligheid.

'n Metode sou wees om die vraelys te koppel aan 'n fisiologiese instrument soos die poligraaf. Die nadeel van die metode is egter dat lesings in " $n$ groot mate afhanklik is van ' $n$ spanningstimulus wat moeilik standaardiseerbaar is. Verder is die poligraaf ook afhanklik van die reaksie van die simpatiese senustelsel wat reageer op ' $n$ bedreiging deur ' $n$ verandering in asemhaling, bloeddruk, hartfrekwensie, breinaktiwiteit en sweetafskeiding.

Daar is dus besluit om die vraelys te evalueer deur middel van onderhoudvoering. Die ondersoeker het hierdie weg gevolg deur soos volg te werk te gaan:

- $\quad$ Die seleksie van 'n monster uit die proefgroep.

- $\quad$ Die monster is verkry deur die grense van spanning vas te stel op $\bar{X} \pm 1$ standaardafwykingseenheid.

- $\quad$ Die groep wat dus "normale" spanning ervaar is 68,26 \% van die monster en is uitgesluit van die onderhoude.

- $\quad 15,87 \%$ van die proefpersone wat val onder die onderste grens van $\bar{X}-1$ standaardafwykingseenheid en $15,87 \%$ van die proefpersone wat val bokant die boonste grens van $\bar{X}+1$ standaardafwykingseenheid is betrek by die onderhoude.

- Aan die hand van die vraelys is kritiese insidente onttrek wat kon aandui of die ervaring soos deur die respondent aangetoon op die vraelys ooreenkom met die inhoud van die vraag. Dit sou ook aan die ondersoeker terugvoering kon gee van die geldigheid van die vraelys wat die bronne van spanning probeer isoleer.

Verder kon die vraelys beperk word tot die frekwensie van spanning aangesien reeds vasgestel is (soos aanstons aangedui sal word) dat daar 'n positiewe verband tussen die frekwensie en intensiteit van spanning bestaan. Voorkeur is gegee aan die frekwensie van spanning omdat hier meer belanggestel is in die herhaling van spanningservarings van verskillende intensiteite as in die voorkoms van 'n enkele intense spanningservaring. Dit was ook moontlik om die vraelys verder te beperk tot die stel van die direkte vrae. 
Die vraelys is verder toegepas op 'n groep van 200 na-uurse en voltydse studente. Die doel hiervan is om soveel as moontlik response te kry om daardeur 'n begin te maak met die vasstelling van norms vir die vraelys.

\section{RESULTATE EN GEVOLGTREKKINGS}

\section{Die verband tussen frekwensie en intensiteit van spanning}

Daar is verwag dat daar 'n positiewe verband tussen die twee elemente op elke vraag sou wees. Die resultate word in Tabel 1 weergegee:

TABEL 1

DIE VERBAND TUSSEN DIE TWEE ELEMENTE VAN SPANNING

(FREKWENSIE EN INTENSITEIT - a en b)

\begin{tabular}{|llc|}
\hline & & $\underline{r}$ \\
Frustrasie & (a) en (b) & 0,502 \\
Angs & (a) en (b) & 0,681 \\
Onsekerheid & (a) en (b) & 0,447 \\
Oorlading & (a) en (b) & 0,498 \\
Kommer & (a) en (b) & 0,400 \\
Konflik & (a) en (b) & 0,450 \\
Verveling & (a) en (b) & 0,601 \\
Verlies aan selfvertroue & (a) en (b) & 0,572 \\
Afhanklikheid & (a) en (b) & 0,531 \\
Aggressie & (a) en (b) & 0,641 \\
Passiwiteit & (a) en (b) & 0,302 \\
\hline
\end{tabular}

$\mathrm{N}=112$

$\mathrm{r}$ : Alle waardes beduidend op die $1 \%$ peil.

Hieruit kan dus afgelei word dat, vir hierdie proefgroep daar 'n positiewe verband bestaan tussen die frekwensie en die intensiteit van spanning soos gemeet deur al die verskillende elemente.

\section{Die voorkoms van elemente}

Uit Tabelle 2, 3 en 4 blyk die volgende:

Afhanklikheid (a) is die element met die hoogste gemiddelde.

Die grootste aantal proefpersone $(43,8 \%)$ het ook alternatiewe 4 en 5 gekies by die beantwoording van die vraag. Afhanklikheid (b) het ook 'n rangorde 6 behaal beide op die gemiddelde van response en die persentasie proefpersone $(18,7 \%)$ wat alternatiewe 4 en 5 gekies het op die beantwoording van die vraag.

Uit die onderhoude het dit geblyk dat die organisasie moontlik, in die afsienbare tyd, op so ' $n$ wyse kan verander dat dit meebring dat van die werkers hulle werk verloor. Op hierdie 
stadium voel die werkers dan ook magteloos teenoor die bedreiging as gevolg van die huidige vraag na arbeid.

Hierby kan die element onsekerheid gevoeg word. Die element het ' $n$ rangorde van 5 behaal op gemiddelde en ' $\mathrm{n}$ rangorde van 3 in die persentasie $(21,5 \%)$ proefpersone wat alternatiewe 4 en 5 gekies het.

Onsekerheid (b) impliseer dan ook die toekomsverwagtings van die werker binne die organisasie.

Frustrasie (a) is die element wat die derde hoogste gemiddelde respons behaal het met ' $n$ rangorde van 2 ten opsigte van die persentasie (22,3\%) proefpersone wat alternatief 4 en 5 gebruik het. Uit die onderhoude blyk dit dan dat die ver naamste struikelblok in die bereiking van doelwitte gesien word as die bevorderingsbeleid.

- $\quad$ Passiwiteit (b) is die element wat 'n rangorde van 4 behaal het op beide gemiddelde en persentasie $(18,8 \%)$ proefpersone alternatief 4 en 5 gekies het. Uit die onderhoude blyk dit dan ook dat die passiwiteit saamhang met die gevoel van afhanklikheid. Alhoewel die bedreiging van werkverlies reël is, voel die werkers dat hulle nie veel hier aan kan doen nie.

Konflik (b) het 'n rangorde van 6 behaal ten opsigte van gemiddelde prestasie en 'n rangorde van 4 ten opsigte van die persentasie mense $(18,8 \%)$ wat alternatiewe 4 en 5 op die vraag gekies het. Uit die onderhoude blyk dit dat van die werknemers voel (veral die wat werksaam is by die takke van die organisasie) dat hulle onmiddellike hoofde nie altyd bekend is met die plaaslike situasie nie. Konflik ontstaan dan hier eerder ten opsigte van die uitvoerbaarheid van opdragte as dit deur die werker beskou word in die lig van die plaaslike toestand.

- $\quad$ Aggressie (a) het ' $n$ rangorde van 8 behaal op beide die gemiddelde responstelling en die persentasie werkers $(17,0 \%)$ wat alternatiewe 4 en 5 gekies het. Uit die onderhoude het dit duidelik geblyk dat die vorm van aggressie nie 'n overte verloor van die humeur is nie maar eerder ' $\mathrm{n}$ veggees (moreel) wat by die proefpersone ontstaan in die normale gang van sake. Aggressie (b), wat meer te doen het met die direkte verloor van die humeur het dan ook 'n rangorde van 13 en 12 behaal. Dit laat die vermoede ontstaan dat aggressie, soos gemeet in (a) niks met spanning te doen het nie. Nogtans is aggressie (a) en (b), deur middel van faktoranalise (Tabel 5), saamgegroepeer onder faktor 4. Dit is duidelik dat hierdie aspek verder ondersoek sal moet word. 


\section{TABEL 2}

\section{DIE GEMIDDELDE RESPONS BEHAAL OP ELKE VRAAG DEUR AL DIE PROEFPERSONE}

\begin{tabular}{|c|c|c|c|c|c|}
\hline Vraag & $\begin{array}{c}\text { Maksimum } \\
\text { Waarde }\end{array}$ & $\begin{array}{l}\text { Minimum } \\
\text { Waarde }\end{array}$ & $\begin{array}{l}\text { Rekenkundige } \\
\text { gemiddelde }\end{array}$ & $\begin{array}{l}\text { Standaard } \\
\text { Afwyking }\end{array}$ & Beskrywing van Vraag \\
\hline 1 & 5 & 1 & 2,78 & 0,93 & Frustrasie (a) \\
\hline 2 & 5 & 1 & 2,42 & 1,05 & Frustrasie (b) \\
\hline 3 & 5 & 1 & 1,69 & 0,83 & Angs (a) \\
\hline 4 & 5 & 1 & 1,62 & 0,87 & Angs (b) \\
\hline 5 & 4 & 1 & 2,34 & 0,75 & Onsekerheid (a) \\
\hline 6 & 5 & 1 & 2,61 & 1,09 & Onsekerheid (b) \\
\hline 7 & 5 & 1 & 2,05 & 0,92 & Oorlading (a) \\
\hline 8 & 5 & 1 & 2,14 & 1,20 & Oorlading (b) \\
\hline 9 & 5 & 1 & 2,49 & 0,96 & Spanning \\
\hline 10 & 5 & 1 & 2,88 & 0,90 & Kommer (a) \\
\hline 11 & 5 & 1 & 2,05 & 0,99 & Kommer (b) \\
\hline 12 & 5 & 1 & 2,46 & 0,96 & Konflik (a) \\
\hline 13 & 5 & 1 & 2,51 & 0,93 & Konflik (b) \\
\hline 14 & 5 & 1 & 1,84 & 0,91 & Verveling (a) \\
\hline 15 & 5 & 1 & 1,52 & 0,82 & Verveling (b) \\
\hline 16 & 4 & 1 & 1,65 & 0,71 & Verlies Selfvertroue (a) \\
\hline 17 & 4 & 1 & 1,71 & 0,82 & Verlies Selfvertroue (b) \\
\hline 18 & 5 & 1 & 3,13 & 1,31 & Afhanklikheid (a) \\
\hline 19 & 5 & 1 & 2,51 & 1,23 & Afhanklikheid (b) \\
\hline 20 & 5 & 1 & 2,49 & 0,96 & Aggressie (a) \\
\hline 21 & 5 & 1 & 2,18 & 0,89 & Aggressie (b) \\
\hline 22 & 5 & 1 & 2,02 & 0,88 & Passiwiteit (a) \\
\hline 23 & 5 & 1 & 2,63 & 1,04 & Passiwiteit (b) \\
\hline 24 & 3 & 1 & 1,18 & 0,43 & Groepsvorming bestuur \\
\hline 25 & 5 & 1 & 1,69 & 0,99 & Verlies vertroue in medemens \\
\hline 26 & 4 & 1 & 1,92 & 0,79 & Verlies vertroue in witte \\
\hline 27 & 4 & 1 & 1,92 & 1,01 & Verwydering eie doelwitte \\
\hline
\end{tabular}


TABEL 3

DIE AANTAL EN PERSENTASIE ( $\left(\begin{array}{l}0 \\ 0\end{array}\right)$ PROEFPERSONE WAT DIE' VERSKILLENDE ALTERNATIELE VIR ELKE VRAAG GEKIES HET

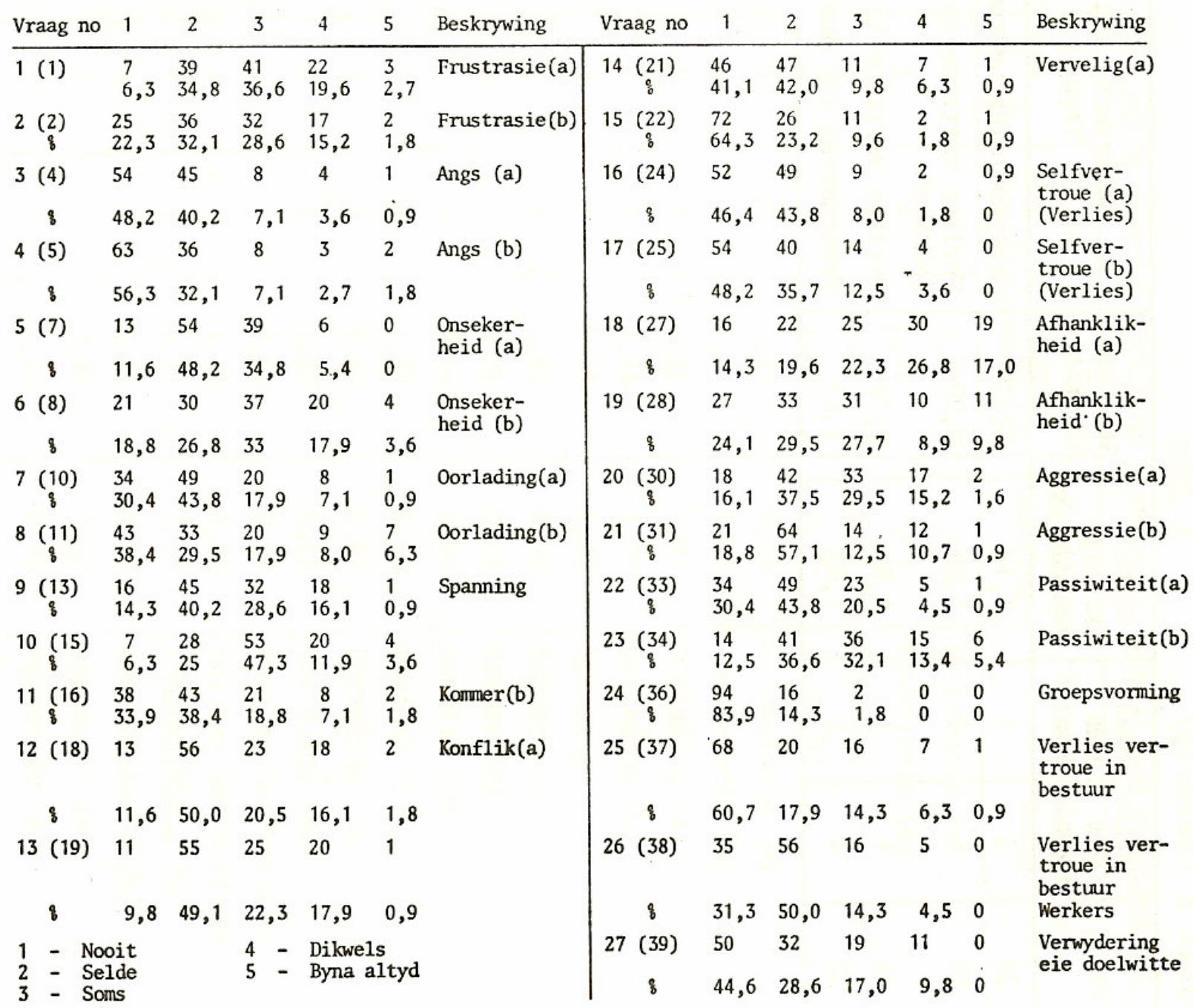


TABEL 4

DIE GEMIDDELDE RESPONSE (TEN OPSIGTE VAN DIE FREKIVENSIE VAN SPANNING) EN DIE PERSENTASIE PROEFPERSONE WAT ALTERNATIEWE 4 EN 5

(DIKWELS EN BYNA ALTYD) GEKIES HET

\begin{tabular}{|c|c|c|c|c|c|}
\hline & & $\overline{\mathrm{X}}$ & Rangorde & $\begin{array}{l}: \text { Proefpersone wat } \\
\text { alternatief } 4 \& 5 \\
\text { gekies het }\end{array}$ & Rangorde \\
\hline Frustrasie & $\begin{array}{l}\text { (a) } \\
\text { (b) }\end{array}$ & $\left|\begin{array}{l}2,78 \\
2,42\end{array}\right|$ & $\begin{array}{r}3 \\
11\end{array}$ & $\begin{array}{l}22,3 \\
17,0\end{array}$ & $\begin{array}{l}2 \\
8\end{array}$ \\
\hline Angs & $\begin{array}{l}\text { (a) } \\
\text { (b) }\end{array}$ & $\begin{array}{l}1,69 \\
1,62\end{array} \mid$ & $\begin{array}{l}22 \\
25\end{array}$ & $\begin{array}{l}4,5 \\
4,5\end{array}$ & $\begin{array}{l}22 \\
22\end{array}$ \\
\hline Onsekerheid & $\begin{array}{l}\text { (a) } \\
\text { (b) }\end{array}$ & $\begin{array}{l}2,34 \\
2,61\end{array}$ & $\begin{array}{r}12 \\
5\end{array}$ & $\begin{array}{r}5,4 \\
21,5\end{array}$ & $\begin{array}{r}19 \\
3\end{array}$ \\
\hline Oorlading & $\begin{array}{l}\text { (a) } \\
\text { (b) }\end{array}$ & $\begin{array}{l}2,05 \\
2,14\end{array}$ & $\begin{array}{l}15 \\
14\end{array}$ & $\begin{array}{r}8,0 \\
14,3\end{array}$ & $\begin{array}{l}16 \\
12\end{array}$ \\
\hline Spanning & & 2,49 & 8 & 17,0 & 8 \\
\hline Konmer & $\begin{array}{l}\text { (a) } \\
\text { (b) }\end{array}$ & $\begin{array}{l}2,88 \\
2,05\end{array} \mid$ & $\begin{array}{r}2 \\
15\end{array}$ & $\begin{array}{r}15,5 \\
8,8\end{array}$ & $\begin{array}{r}11 \\
5\end{array}$ \\
\hline Konflik & $\begin{array}{l}\text { (a) } \\
\text { (b) }\end{array}$ & $\left|\begin{array}{l}2,46 \\
2,51\end{array}\right|$ & $\begin{array}{r}10 \\
6\end{array}$ & $\begin{array}{l}17,9 \\
18,8\end{array}$ & $\begin{array}{r}7 \\
4\end{array}$ \\
\hline Verveling & $\begin{array}{l}\text { (a) } \\
\text { (b) }\end{array}$ & $\begin{array}{l}1,84 \\
1,52\end{array} \mid$ & $\begin{array}{l}20 \\
26\end{array}$ & $\begin{array}{l}7,2 \\
2,7\end{array}$ & $\begin{array}{l}17 \\
25\end{array}$ \\
\hline Selfvertroue & $\begin{array}{l}\text { (a) } \\
\text { (b) }\end{array}$ & $\begin{array}{l}1,65 \\
1,71\end{array} \mid$ & $\begin{array}{l}24 \\
21\end{array}$ & $\begin{array}{l}1,8 \\
3,6\end{array}$ & $\begin{array}{l}26 \\
24\end{array}$ \\
\hline Afhanklikheid & $\begin{array}{l}\text { (a) } \\
\text { (b) }\end{array}$ & $\left|\begin{array}{l}3,13 \\
2,51\end{array}\right|$ & $\begin{array}{l}1 \\
6\end{array}$ & $\begin{array}{l}43,8 \\
18,7\end{array}$ & $\begin{array}{l}1 \\
6\end{array}$ \\
\hline Aggressie & $\begin{array}{l}\text { (a) } \\
\text { (b) }\end{array}$ & $\begin{array}{l}2,49 \\
2,18\end{array}$ & $\begin{array}{r}8 \\
13\end{array}$ & $\begin{array}{l}17,0 \\
11,6\end{array}$ & $\begin{array}{r}8 \\
12\end{array}$ \\
\hline Passiwiteit & $\begin{array}{l}\text { (a) } \\
\text { (b) }\end{array}$ & $\left|\begin{array}{l}2,02 \\
2,63\end{array}\right|$ & $\begin{array}{r}17 \\
4\end{array}$ & $\begin{array}{r}5,4 \\
18,8\end{array}$ & $\begin{array}{r}19 \\
4\end{array}$ \\
\hline \multicolumn{2}{|l|}{ Groepsvorming } & 1,18 & 27 & 0,0 & 27 \\
\hline \multicolumn{2}{|c|}{ Verlies vertroue bestuur } & $1,69 \mid$ & 22 & 7,2 & 17 \\
\hline \multicolumn{2}{|c|}{ Verlies vertroue medewerkers } & 1,92 & 18 & 9,8 & 14 \\
\hline
\end{tabular}


Ook spanning het ' $n$ rangorde van 8 behaal op beide die gemiddelde responstelling en die persentasie werkers $(17,0 \%)$ wat alternatiewe 4 en 5 gekies het. Uit die onderhoude het dit duidelik geblyk dat die werkers 'n vae begrip het van spanning. By die versoek dat die begrip spanning omskryf moet word is beskrywings gegee van frustrasie (teenstrydig met faktoranalise), oorlading (in ooreenstemming met faktoranalise) en konflik (teenstrydig met faktoranalise).

- $\quad$ Angs word oor die algemeen beskou as ' $n$ indikator of voorloper van meer ernstige stoornis. Daarom is die rangordes van 22 en 22 vir angs (a) en 25 en 22 vir angs (b) te wagte. Tydens die onderhoude kon net een van die respondente egter ' $n$ bevredigende verklaring gee van wat angs is wat die vermoede laat ontstaan dat:

$+\quad$ Angs as sulks 'n emosionele ervaring is wat van binne kom en dus die rasionele meting (direk) daarvan weerstaan - dit is as aanvaar word dat angs teenwoordig is.

$+\quad$ Angs vir die deursnee mens onverklaarbaar is. (Wat ooreenstem met die definiëring van die begrip).

Die feit dat groepsvorming teen bestuur die laagste rangorde behaal het wil nie noodwendig impliseer dat geen informele groepe teenwoordig was nie. Tydens die onderhoude is sterk aanduidings gevind van informele groepstrukture. Aangesien die kommunikasie tussen die bestuur en die werker egter van hoogstaande aard is word die groepsvorming egter nie gerig teen bestuur nie.

\section{Die isolering van elemente}

Dit is duidelik uit tabel 5 dat die begrip spanning bloot ' $n$ versamelnaam is. Die vraag is doelbewus in die vraelys ingebou om te sien of die respondente gaan onderskei tussen die verskillende elemente waaruit spanning bestaan. Volgens die resultate (faktor 1) blyk dit dat die ondersoekgroep spanning assosieer met oorlading, dit wil sê dat die persoon meer werk het om te doen as wat hy die tyd voor het. Spanning word ook geassosieer met kommer. Dit het ook uit die onderhoude geblyk dat die kommer terugslaan op beide kwaliteit en kwantiteit van die werk wat gedoen word. Die meeste respondente het gevoel dat hulle dikwels nie die tyd het om die werk so goed te doen as wat hulle wou nie en hieroor het hulle hulle bekommer. Die element kan genoem word oorlading.

Die tweede element kan frustrasie genoem word (faktor 2). Dit is duidelik dat frustrasie en aggressie nie saamhang nie wat weereens 'n vraagteken agter die frustrasie-aggressie hipo- 
tese plaas. Frustrasie hang egter wel saam met 'n verlies aan vertroue in die hoof en verwydering van die doelwitte van die organisasie. Uit die onderhoude het dit ook sterk na vore gekom. Van die respondente het gevoel dat:

- Dit onregverdig is van sommige van die hoofde om van die werkers te verwag om gemotiveerd op te tree terwyl van die hoofde self druk besig is om rond te kyk vir ander werk.

- $\quad$ Die hoofde nie genoeg erkenning gee vir kreatiwiteit en individualiteit nie.

- Die groeibehoefte moeilik in 'n organisasie wat (al is dit vaagweg) bedreig word met moontlik oorname, bevredig kan word.

\section{$\underline{\text { TABEL } 5}$}

\section{'N FAKTORANALISE VAN DIE ELEMENTE WAARUIT SPANNING BESTAAN}

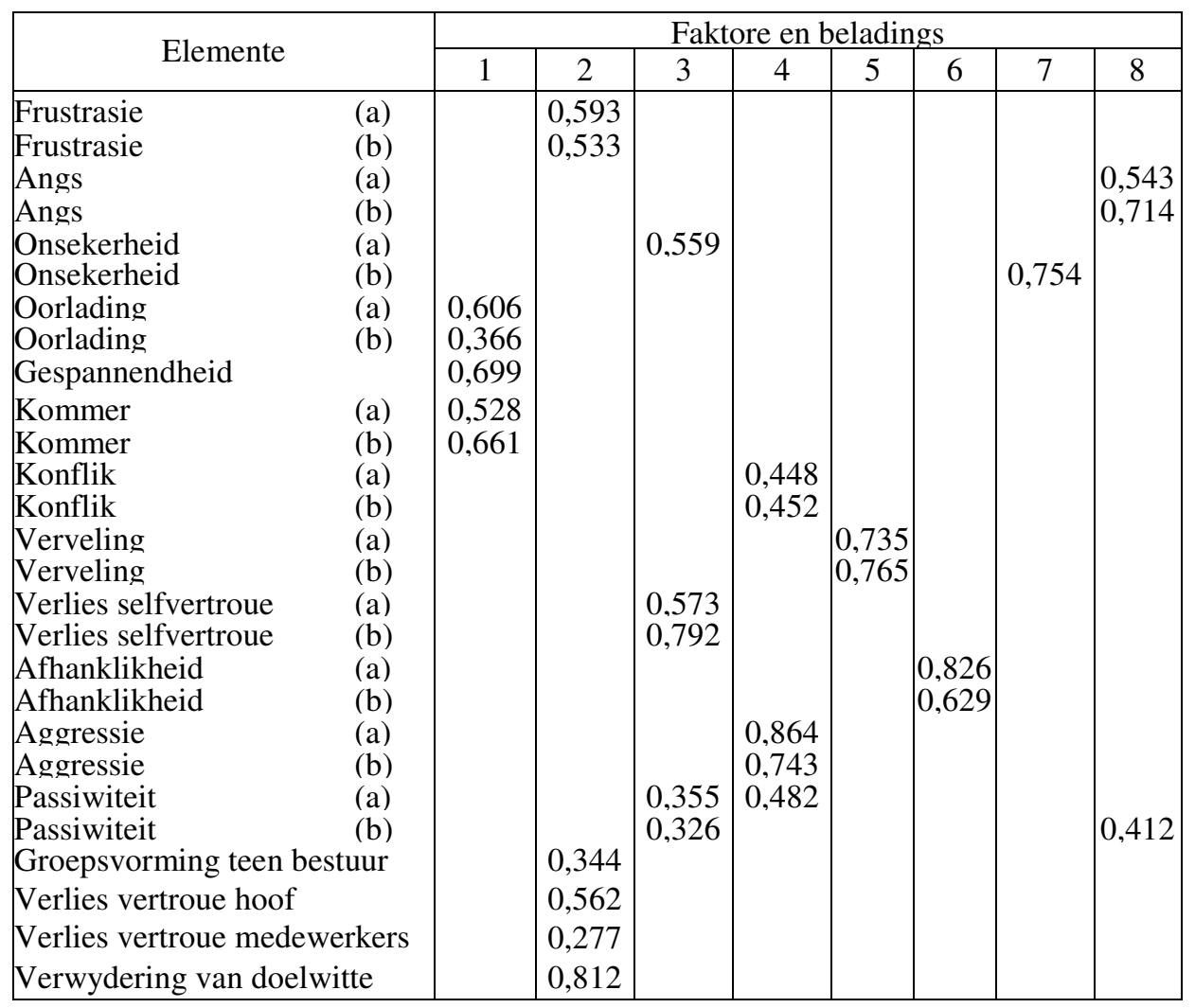

Die elemente groepsvorming teen bestuur en verlies aan vertroue in medewerkers kon nie in die onderhoude opgehelder word nie. $\mathrm{Al}$ die respondente met wie onderhoude gevoer is, met die uitsondering van een, het lae tellings op die elemente behaal. Die een wat wel 'n hoë telling behaal het, kon nie ' $n$ kritiese insident, of selfs ' $n$ bevredigende omskrywing van die elemente weergee nie. 
Die derde element (faktor 3) kan beskryf word as onsekerheid. Die vraag wat onsekerheid (a) toets het direk te doen met die werksituasie self. Uit die onderhoude het hier egter 'n onverwagte aspek na vore gekom. Die ondersoek het naamlik die gevoel gekry dat die onsekerheid nie presies gaan oor hoe om die werk fisies te doen nie maar eerder om:

- Onsekerheid ten opsigte van neem van besluite (areas van vryheid)

- Onsekerheid ten opsigte van delegering van gesag.

- Onsekerheid ten opsigte van verantwoordelikheid.

- Onsekerheid ten opsigte van gehalte van prestasie (terugvoering).

Daarom is die koppeling van onsekerheid (a) met die verlies aan selfvertroue (a) en (b) geen verrassing nie. Die vraag ontstaan egter nou: het "n lae selfbeeld aanleiding gegee tot die onsekerheid of het die onsekerheid 'n gebalanseerde selfbeeld afgebreek tot ' $n$ lae selfbeeld? Die koppeling van passiwiteit (a) en (b) kan miskien die eerste alternatief suggereer. Om die vraag bevredigend te beantwoord sou mens egter:

- 'n Deeglike persoonlikheidsanalise van die respondente doen.

- Die faktor van jare diens in die organisasie, of die tydperk van blootstelling aan die onsekerheid, in aanmerking neem.

Faktor 7 kan ook as 'n onderdeel van onsekerheid beskou word. Die (b) gedeelte van die vraag het meer betrekking op die toekomsverwagtings van die werker binne die spesifieke organisasie. Volgens die ontleding staan die element dan ook heeltemal alleen. Uit die onderhoude het dit geblyk dat onsekerheid ten opsigte van toekomsverwagtings ook terugverwys word na die bevorderingsbeleid of - prosedure binne die organisasie. Die organisasiestruktuur het ook meegebring dat van die respondente voel dat dit fisies nie moontlik is om bevorder te word nie. Voeg daarby die onsekerheid of die organisasie nog gaan voortbestaan en die onsekerheid kan begryp word.

Die vierde element (faktor 4) kan beskryf word as konflik wat verband hou met aggressie. Die verband is nie baie duidelik nie. Nie een van die proefpersone waarmee onderhoude gevoer is toon 'n eksplosiewe persoonlikheidstendens nie. In die literatuur kan ook geen direkte bevredigende verklaring gevind word vir " $n$ moontlike verband tussen aggressie en konflik nie. Konflik by 'n persoon wat gerig is op probleemoplossingsgedrag bring ook nie noodwendig aggressie mee nie, behalwe as die voorkoms van overte aggressie (element (b)) geïgnoreer word en slegs gekonsentreer word op (a) wat, soos gesien tydens die onderhoude, meer betrekking het op moreel. 
Die vyfde element (faktor 5) kan beskryf word as belangeloosheid. Die element het egter " $n$ lae rangorde behaal op die voorkoms van die element. Tydens die onderhoude kon die ondersoeker geen aanduiding kry van verveling nie. Die voorkoms van verveling, by ' $n$ individuele analise van die vraelyste, blyk ook weer voor te kom by werkers wat die organisasie bloot gebruik as " $n$ bron van inkomste terwyl hulle studeer vir hulle werklike beroepe. Verveling moet dus nie gesien word as 'n gevoel wat ontstaan by die werker omdat hulle te min het om te doen nie maar omdat hul geen belang het in wat hulle doen nie. Die koppeling van passiwiteit (a) hieraan kan dus verstaan word.

Dit sou ook moeilik wees om oorlading/spanning/kommer - "n faktor wat 'n hoër rangorde behaal het - te koppel aan verveling in die spesifieke organisasie. By ' $n$ verdere ondersoek sou dit miskien goed wees om verveling te vervang met belangeloosheid.

Die sesde element (faktor 6) kan dan ook genoem word afhanklikheid. Aangesien heelwat hierop uitgebrei is in 'n vorige paragraaf word hiermee volstaan.

Die sewende element (faktor 8) kan as angs beskryf word. Alhoewel angs ' $n$ lae rangorde behaal het (kyk Tabel 4) het die ondersoeker nogtans, tydens die onderhoud, hierop ingegaan. Die gevolgtrekkings word in 'n latere paragraaf weergegee.

\section{KRITIEK TEEN DIE ONDERSOEK}

Die groot aantal werknemers (136 uit 300) wat nie aan die ondersoek deelgeneem het nie, wek kommer. Aan die ander kant maak die hoogs vertroulike aard van die response dit onmoontlik om op enige geforseerde wyse response te bekom.

Van die vrae is nie verstaan nie. In 'n biografiese vraelys wat ingesluit was het die ondersoeker gevra of daar enige vrae is wat nie verstaan is nie. Die begrip "passiwiteit" het vir twee respondente (en 'n mens vermoed dan vir 'n hele klomp) probleme gegee.

Die vraag oor onsekerheid (b) kan meer as een ding beteken. Die eerste helfte van die vraag het meer te doen met die onmiddellike terwyl die tweede gedeelte meer te doen het met die toekoms.

Die vertroulikheid en intiemheid van die inligting stem die respondent onrustig. As voorbeeld kan genoem word die reaksie van een respondent: ... "As die inligting in die verkeerde mense se hande val is al die eerlikes hulle werk kwyt ... " 
Afgesien van die vraelys wat hier bespreek is is ook die volgende vraelyste by die ondersoek betrek:

' $n$ Vraelys om die ervaarde bestuurstyl in die organisasie te bepaal. Die vraelys is gebaseer op die aannames van McGregor, Blake en Mouton en Argyris. Voorlopige resultate dui daarop dat daar "n moontlike verband bestaan tussen die frekwensie van spanning en die sogenaamde "harde" bestuurstyl.

'n Vraelys om die bronne van spanning te bepaal. Die vraelys is gebaseer op die areas van belangrikheid soos vasgestel deur Hertzberg. Die intensiteit van die behoefte is eers vasgestel en toe die mate waarin die behoefte bevredig is.

'n Vraelys om 'n eie evaluering van persoonlikheid te kry. Hiermee poog die ondersoeker dan om vas te stel of die selfbeeld enige verband het met die ervaring van spanning.

'n Vraelys om werkstevredenheid te meet. Voorlopige resultate dui daarop dat daar 'n moontlike verband is tussen die frekwensie van spanning en werkstevredenheid.

'n Uitgebreide biografiese vraelys waardeur die ondersoeker gaan probeer om:

- $\quad$ Enkele traumatiese insidente te isoleer.

- $\quad$ Die moontlike effek van ander omgewings op die ervaring van spanning in die werk te bepaal.

Die ondersoeker is van mening dat die vraelys wel spanning meet. Die vraelys moet egter nog op veel meer mense toegepas word om die vraagstelling na behore te beantwoord.

Daar is duidelik vasgestel dat daar ' $n$ verband is tussen die frekwensie en die intensiteit van spanning soos dit ervaar is in die werksituasie. ' $n$ Mens moet egter versigtig wees om die verband ook te gaan soek in ander omgewings.

Dit is duidelik dat spanning in sewe duidelik waarneembare elemente ingedeel kan word naamlik:

Oorlading

Frustrasie

Onsekerheid

Konflik 
Belangeloosheid

Afhanklikheid

Angs

Dit is ook duidelik dat daar sekere elemente is wat meer voorkom as ander. Dit moet egter in gedagte gehou word dat hier twee belangrike aspekte is wat veralgemening van die resultate nie moontlik maak nie:

- Die beperktheid van die totale aantal proefpersone wat aan die ondersoek deelgeneem het.

- $\quad$ Die uniekheid van die organisasie waarin die ondersoek gedoen is.

Veel verdere navorsing moet nog gedoen word voordat hier enige sprake is van veralgemening.

\section{OPSOMMING}

Die ondersoek is daarop gerig om 'n vraelys te ontwikkel wat werkspanning meet. Verder word die elemente of ervarings waaruit werkspanning bestaan, asook daardie ervarings wat die meeste voorkom, geïsoleer. Die ondersoek is gedoen deur 'n omvattende vraelys toe te pas op 112 blanke werknemers werksaam by 'n streekstak van 'n landswye organisasie en wat opgevolg is deur onderhoude op 'n streekproefbasis. Sewe ervarings is geïsoleer, naamlik oorlading, frustrasie, onsekerheid, konflik, belangeloosheid, afhanklikheid en angs. Die ervaring met die hoogste responsgemiddelde is afhanklikheid terwyl die ervarings kommer, frustrasie en onsekerheid die tweede, derde en vierde hoogste responsgemiddelde respektiewelik behaal het.

\section{VERWYSINGS}

Altorfer, O. Emotional Job Fitness: The Education of the Heart. Personnel, September Oktober 1975, 32-37

Appley, M.H. en Trumbull, R. Psychological Stress: Issues in Research. New York:

Appleton-Century-Crofts, 1967.

Argys, C. Personality and Organization. The Conflict between System and the Individual. New York: Harper \& Row, 1957.

Buck, V. E. Working under Pressure. London: Staples Press, 1972.

Caplan, R.D. en Jones, K.W. Effects of work load, role ambiguity and type a personality on anxiety, depression and heart rate. Journal of Applied Psychology, 1975, 60(6), 713 719.

Cochrane, R. en Robertson, A. Stress in the lives of parasuicides. Social Psychiatry, 1975, 10, 161-171. 
Doll, R. en Jones, A.F. Occupational Factors in the Aetiology of Gastric and Duodenal Ulcers. Medical Research Council Special Report Series, No. 276 London, H.M.S.O. 1951.

French, J.R.P. en Caplan, R.D. Organizational Stress and Individual Strain. in Marrow, A.J. (Red.) The Failure of Success. New York: American Management Association, 1972.

Gosling, R.H. Peptic ulcer and mental disorder. Journal of Psychosomatic Research, 1958, 2 , 285-301.

Kornhauser, A. Mental-Health of the Industrial-Worker: A Detroit Study. New York: Wiley, 1965.

Lazarus, R.S. Patterns of Adjustment and Human Effectiveness. New York: McGraw-Hill, 1969.

Levinson, H. The Exceptional- Executive. A Psychological Conception. Cambridge: Harvard University Press, 1968.

Mahl, G.F. Anxiety, H.C.L. Secretion and peptic ulcer etiology. Psychosomatic Medicine, 1949, II, 30-44.

McLean, A. (Red.) Occupational- Stress. Springfield: Thomas Publisher, 1974.

Pfanz, M., Rosenstein, E. en von Euxkull, P.T. Socio-psychological Aspects of Peptic Ulcer. Journal of Psychosomatic Research, 1965, 1, 68-74.

Rogers, R.E. en Colbert, J.T.C. Drug abuse and organizational response: A review and evaluation. Personnel Journal, 1975, 54(5), 266-271 en 281.

Sales, S.M. Some effects of role overload and role underload. Organizational Behavior and Human Performance, 1970, 5, 592-608.

Seyle, H. The Stress of Life. New York: McGraw-Hill, 1956.

Snyder, D. Institutional setting and industrial conflict: Comparative analyses of France, Italy and the United States. American Sociological Review, 1975, 40, 259-278.

Vertin, P.G. Bedryfsgeneeskundige Aspecten van het Ulcus Pepticum. Thesis, Groningen. Hermes, Eindhoven, 1954. 